\title{
PERAN AYAH DALAM PERSPEKTIF ISLAM DAN IMPLEMENTASINYA TERHADAP SISWA MADRASAH ALIYAH NEGERI (MAN) DI JAKARTA
}

\author{
Bunyanul Arifin* \\ abunyanul@yahoo.com \\ *Dosen Magister Pendidikan Agama Islam, Universitas Muhammadiyah Tangerang
}

\begin{abstract}
Father's role in children is very important. The child's success is determined by the way the father treats his child. The purpose of this study is to empirically analyze the concepts of fathers and their role in children in an Islamic perspective and measure the level of implementation in the field. Type of descriptive qualitative research with respondents of 500 MAN students in West Jakarta. Data obtained through; observation, questionnaire, and interview. Also from written documents, drawings and literature studies. In this study the author formulates the role of the father into six dimensions, namely the role as; 1) leaders, 2) providers of economic needs, 3) protectors, 4) educators, 5) playmates, 6) friends. The study concluded that father's role in children in Islamic perspective was $44(\%)$. The highest role as a protector $64(\%)$, then the economic provider $60.8(\%)$. The lowest role as a friend is 25.3 (\%), then a friend plays $29(\%)$. Leader's role is $44.7(\%)$, and as an educator $40.8(\%)$. The conclusion of the study is that the implementation of the role of fathers in an Islamic perspective is relatively small, and needs further research on their influence on children.
\end{abstract}

Keywords: Father, Job Science, Concept of Islam, Parenting, Role of Muslim Fathers

\section{A. PENDAHULUAN}

Pendidikan dan pengasuhan orang tua adalah pondasi dasar bagi pembentukan karakter dan kepribadian seseorang sekaligus menjadi faktor kunci bagi keberhasilan dan kebahagiaan dalam kehidupannya. Pandangan umum yang terjadi di masyarakat biasanya menunjuk ibu sebagai pihak yang paling berperan sekaligus bertanggungjawab terhadap pendidikan dan perilaku anak-anaknya. Seorang ayah dianggap wajar jika tidak memberikan banyak waktu untuk mendidik anaknya dirumah karena ayah dianggap penanggung jawab kebutuhan materi saja.

Pandangan bahwa peran ayah kepada anak hanya sebagai pencari nafkah atau Breadwinner ternyata bukan hanya terjadi di kalangan masyarakat biasa pada umumnya. Di kalangan masyarakat terdidik sekalipun cara pandang demikian juga masih terjadi. Misalnya apa yang ditulis oleh Charlety Choesyam Sofar pada disertasinya di UIN Jakarta tahun 2008 (Charlety, 2008).

Sejumlah penelitian menyebutkan bahwa kajian terhadap peranan ayah terhadap anak terlalu sedikit dibandingkan dengan studi yang mengupas peran ibu yang sudah banyak dikaji secara mendalam. The National Center For Education Statistic (NCES), sebuah lembaga Riset dan Pengembangan di Departemen Pendidikan Amerika Serikat menyebutkan bahwa sejak beberapa dekade silam, kajian anak dan isuisu tentangnya cenderung hanya fokus terhadap anak dan ibu serta melupakan dan menafikan ayah (NCES, 1997).

Sejumlah kajian kontemporer bahkan menegaskan betapa pentingnya peran ayah dalam pengasuhan anak yang meliputi banyak hal. Pada tahun 1988, organisasi nirlaba Family Support Act telah menaruh 
perhatian secara serius akan resiko dan bahaya ketiadaan ayah dalam kehidupan anak. Alarm peringatan itu terbukti dengan hasil survei di beberapa negara maju seperti Amerika misalnya, seperti yang diungkapkan oleh Edward Kurk (2015), seorang Associate Profesor ilmu-ilmu sosial di British Columbia University, ia menyatakan bahwa:

a. Ketiadaan peran ayah terhadap anak menyebabkan 70 persen siswa drop out dari sekolah

b. Menyebabkan rendahnya prestasi akademik, menyebabkan siswa terlibat kejahatan dan perbuatan kriminal (85 persen remaja yang di penjara disebabkan ketiadaan peran ayah)

c. Menjadi penyebab penyimpangan perilaku seksual pada remaja (hamil di luar nikah, perilaku seks bebas, dll)

d. Menjadi penyebab remaja terjerumus pada narkotika dan obat-obatan terlarang

e. Menjadi penyebab remaja tidak betah di rumah (90 persen remaja yang kabur dari rumah karena ketiadaan peran ayah dalam kehidupannya).

Pada era sebelum tahun 1970-an, kajian dan kebijakan tentang perkembangan keluarga lebih didominasi tentang keluarga inti yang menempatkan ayah hanya sebagai pencari nafkah atau penanggungjawab kebutuhan ekonomi dan ibu sebagai penanggungjawab dalam perawatan dan pengasuhan anak-anak. Hal ini bisa dilihat pada kajian-kajian yang telah dilakukan oleh Coltrane dan Parke pada tahun 1998, Gottman dan Katz pada tahun 1989, Parke pada tahun 1996, dan Pruett pada tahun 1998 (Darity, 2008). Karena itulah Michael E. Lamb, salah satu ilmuwan perintis kajian ini, mengatakan bahwa ayah adalah the forgotten contributor (kontributor yang terlupakan), karena perannya yang amat sentral tetapi seringkali dilupakan. Padahal mengabaikan peran ayah sama saja membiarkan terjadinya bias dalam penelitian perkembangan anak (Lewis, Lamb, 2003). Muna Erawati menyatakan bahwa semenjak penelitian Lamb yang dibukukan dalam bunga rampainya yang berjudul The Role of The Father in Child Development (1981), penelitian tentang peranan ayah banyak dilakukan di Amerika Serikat

Buku-buku dan kajian ilmiah, ilmu atau teori yang membahas tentang ayah dan segala hal yang berkaitan dengannya disebut dengan istilah Fathering atau KeAyahan. Kajian ini terhitung sesuatu yang baru, bahkan di Amerika, Australia dan Eropa sekalipun. Beberapa penulis yang meneliti kajian ini menyebutkan bahwa Fathering baru menarik minat para peneliti mulai tahun 1970-an (Cabrera, 2002). Menyadari pentingnya peran ayah terhadap anak ini maka pada tahun 1995 presiden Clinton menyampaikan memorandum yang meminta semua depertemen dan lembagalembaga penting lainnya di Amerika saat itu untuk fokus dan serius menjadikan "ayah" sebagai isu utama yang masuk dalam program, kebijakan, dan kajian-kajian kebijakannya (NCES, 2015).

Beberapa negara Barat seperti Inggris, Perancis, dan Amerika Serikat, menurut Lamb, pada akhirnya menyadari dan telah menempatkan ayah sebagai sosok yang paling berperan dan memiliki otoritas serta pengaruh terhadap semua properti keluarga termasuk tanah, istri dan anak. Seorang ayah juga berperan pada pertumbuhan dan perkembangan moral-spiritual sekaligus dalam pembentukan kedisiplinan mereka (Parke, 2003). Pleck dan Pleck (1997) juga menegaskan bahwa pola baru hubungan ayah dan anak ini dipercaya akan membawa pada kematangan pengasuhan dan pendidikan keluarga yang akan berpengaruh besar pada karakter anak.

Fathering semakin berkembang dan ramai diperbincangkan sebagai kajian ilmiah, diskusi publik sekaligus menjadi kajian kebijakan sejak tahun 1990-an (Darity, 2008). Pada tahun 1981, Michael E. Lamb -ilmuwan penting yang mempelopori kajian ini-, telah membuat rumusan tentang tiga dimensi peran ayah terhadap anak. Dalam bukunya The Role of The Father in Child Development (1981) Lamb membagi peran ayah dalam tiga dimensi yaitu ; Interaksi, kesediaan waktu, 
dan tanggung jawab (NCES, 2001). Dalam kajian lain oleh Jain, Belsky dan Crnic (1996), peran ayah dapat dikategorikan ke dalam empat tipe; (1) Pengasuh, (2) Guru dan Teman, (3) Pengontrol kedisiplinan, dan (4) Pengawas. Sedangkan menurut Hart (1999), peran ayah terhadap anaknya adalah sebagai; (1) Pencari nafkah, (2) Sahabat dan teman bermain, (3) Perawat, (4) Guru dan teladan, (5) Pengawas dan pengontrol disiplin, (6) Pelindung, (7) Menyuruh, dan (8) Sebagai sumber (Belsky, K.Crcnic, 2015).

Teori Fathering lain disampaikan Evans (1999), baginya peran ayah pada umumnya disimpulkan pada dengan Five Ps atau lima Ps, yaitu; (1) Pemberi solusi, (2) Teman bermain, (3) Pemberi hukuman, (4) Pemberi dan, (5) Penyedia . Kesimpulan berbeda tentang peran ayah disebutkan Rilley dan Shalala (2000) dan Brown (2000) menjawab pertanyaan, "What's special about Father's Involvement?". Ketiganya berkesimpulan bahwa seorang ayah memiliki peran yang spesial sebagai; (1) Teladan sebagai laki-laki dewasa, (2) Pembuat keputusan, (3) Pemberi solusi, (4) Penyedia kebutuhan keuangan dan pemberi motivasi.

Selanjutnya Hilliard (1996) merumuskan peran ayah dalam hubungannya dengan anak menjadi tiga faktor yaitu; Komunikasi, Komitmen, dan Keagamaan. Sementara itu pengamatan McAdoo (2002) terhadap keluarga di Amerika Serikat berkaitan dengan peran ayah adalah sebagai; (1) penyedia dan pemberi fasilitas, (2) pemberi perlindungan), (3) pembuat keputusan, (4) pendidik dan ahli tentang anak, dan (5) pendamping ibu dalam pengasuhan.

Beberapa studi lain tentang peran ayah secara spesifik dikaitkan dengan pendidikan anaknya di sekolah terdapat beberapa pendapat antara lain Seiderman dalam Parenting Pathaways (1998) yang mengatakan bahwa peran ayah dalam pendidikan anaknya adalah : (1) meluangkan waktu bersama anak sebanyak mungkin, (2) mengambil peran aktif dalam perkembangan anak, (3) terlibat dalam proses pendidikan anak, (4) menjadi teladan bagi anak, (5) memastikan anak dalam kondisi sehat

Slameto dalam penelitiannya tentang peran ayah dalam pendidikan anak dan hubungannya dengan prestasi belajarnya menyimpulkan peran ayah menjadi; penyedia fasilitas belajar, (2) pendidik, (3) pembimbing, (4) model atau teladan. Untuk kebutuhan penelitian dalam menilai dan mengukur peran seorang ayah terhadap anak maka lembaga National Center on Father and Families (NCOFF, 2001) yang berbasis di Amerika Serikat telah mengembangkan indikator peran ayah sebagai berikut; (1) Father Presence atau kehadiran ayah dalam kehidupan anak yang mencakup Engagement, Availability, dan Responsibility, (2) Care-giving yang meliputi pengasuhan, perawatan, kesehatan dan penampilan, (3) Social competence, yaitu suatu upaya untuk mengembangkan kemampuan dan kecerdasan sosial, (4) Cooperative Parenting, yaitu membangun hubungan yang positif untuk mengoptimalkan perkembangan anak, (5) Father's healthy living, yaitu menjadi model dalam kesehatan, pendidikan dan perilaku sosial, (6) Material and financial contribution, yaitu menyediakan segala kebutuhan keuangan dan kebutuhan material lainnya.

Tidak jauh berbeda dengan apa yang dirilis oleh NCOFF, lembaga National Center For Education Statistic (NCES, 2001), sebuah lembaga Riset dan Pengembangan di Departemen Pendidikan Amerika Serikat, merilis dan merangkum peran ayah terhadap anak menjadi tujuh bidang yang merupakan ringkasan dan kesimpulan dari sejumlah pendapat dan hasil riset para ahli seperti Amato (1987, 1996), McBride (1990), McBride dan Mills (1993), Palkovitz (1997), Radin (1994), Volling dan Belsky (1991). Tujuh peran ayah tersebut adalah : (1) Economic Provider, yaitu ayah sebagai penyedia kebutuhan ekonomi keluarga anak, (2) Caregiver and Nurturer, makna caregiver adalah ayah berperan pada kebutuhan perawatan anak seperti memandikan, 
membersihkan,atau memberi makan anak. Sedangkan nurturer berarti ayah berperan dalam pengasuhan dan terlibat secara emosi seperti mencium, membelai, memeluk dan memanggilnya dengan panggilan kesayangan, (4) Teacher and Role model, yaitu ayah berperan mendidik anak sekaligus sebagai teladan bagi anak, (5) Friends and Playmates, yaitu ayah berperan sebagai sahabat dan teman bermain bagi anak, (6) Monitors and disciplinarian, yaitu ayah sebagai pengawas dan yang mengontrol kedisiplinan, sikap, dan perilaku anak, dan (7) Protector, yaitu peran ayah sebagai pelindung bagi anak.

Teori-teori Fathering yang telah disebutkan diatas dibangun atas dasar filosofi dan epistemologi keilmuan yang berkembang di Barat yang tentu dalam beberapa aspek berbeda dengan bangunan keilmuan Islam yang bersumber kepada dua hal, yaitu; pertama sumber Ilahi atau wahyu berupa Al-Qur'an dan Sunnah, dan yang kedua adalah sumber dari manusia yang berupa ijtihad dan usaha-usaha penelitian dan pengkajian yang dilakukan oleh manusia yang bermanfaat bagi kemanusiaan pada umumnya serta tidak bertentangan dengan prinsip-prinsip syariat Islam (Ulwan, 2013).

Riset dan kajian tentang peran ayah terhadap anak dalam perspektif Islam dapat dikatakan belum cukup memadai. Pada umumnya buku-buku tentang peran orang tua terhadap anak atau Islamic Parenting bersifat teoritis-filosofis seperti buku klasik karya ulama kenamaan Ibnu Qayyim AlJauziyah, Tuhfat al-Maudud Fi ahkam alMaulud. Dan juga buku yang sudah cukup populer karya Abdullah Nasih Ulwan, Tarbiyat Al-Aulad Fi al-Islam. Sebagian buku-buku tersebut bersifat praktis dan aplikatif seperti yang ditulis oleh para ahli parenting di Indonesia misalnya yang ditulis oleh Irawati Istadi, Ihsan Baihaki Ibnu Bukhari, Muhamad Fauzil Adzhim, dan lain-lain yang kebanyakan bersifat umum dan bukan hasil riset serta tidak spesifik berbicara tentang ayah.

Karya ilmiah dengan tema peran ayah dari sudut pandang Islam penulis dapatkan pada disertasi karya Adnan Hasan Shalih Baharits di Universitas Ummul Qura, Saudi Arabia, pada tahun 1991. Disertasi ini telah diterjemahkan dan diterbitkan oleh penerbit Gema Insani pada tahun 2007 dengan judul Mendidik Anak Laki-laki, sedangkan judul asli tulisan ini adalah "Mas'uliah al-Ab alMuslim Fi Tarbiyah Al-Awlad Fi Marhalah At-Tufuliyah". Meskipun demikian tulisan ini lebih menyoroti peran ayah terhadap anak laki-laki pada fase kanak-kanak saja dan hanya berhenti pada konsep dan teori saja dan kurang memberikan fakta-fakta yang berkaitan dengan tema tersebut.

Berdasarkan hasil kajian atas teori Fathering yang berkembang serta telaah atas sumber-sumber primer ajaran Islam dan karya-karya para ulama tersebut maka penulis merumuskan enam teori peran ayah yaitu:

1. Peran ayah sebagai Pemimpin (Leader). Dengan dasar Al-Qur'an Surat An-Nisa (4: 34), dan Hadis Shahih riwayat Abdullah bin Umar r.a : "Setiap kalian adalah pemimpin dan setiap pemimpin akan diminta pertanggung jawaban atas yang dipimpinnya". (Bukhari, no. 2554).

2. Peran ayah sebagai Penyedia Kebutuhan Ekonomi (Economic Provider), dengan dasar Al-Qur'an surat Al-Baqarah (2:23), Q.S an-Nisa (4:34), dan Q.S AtTalaq (65:7), dan dalam hadits pada Shahih Bukhari yang diriwayatkan dari Abu Mas'ud Al Anshari (Bukhari, no. 4932). Juga dalam hadits riwayat Abu Dawud (Ulwan, 2013).

3. Peran ayah sebagai Pelindung (Protector) dengan dasar dari nash AlQur'an dan Sunnah antara lain kisah Nabi Ibrahima.s dengan putranya Nabi Ismail a.s, kisah Nabi Ya'qub a.s dengan anak-anaknya termasuk dengan putranya Yusuf a.s. Juga termasuk kisah Nabi Nuh a.s dengan anaknya Kan'an. Dan juga kisah Nabi SAW dalam menjaga dan melindungi anak-anaknya sebagaimana dijelaskan dalam hadits dan buku-buku sejarah (Abadzhah, 2007).

4. Peran ayah sebagai Pendidik (Educator) dengan dasar Q.S Al-Jumu'ah (62:2), dan hadits riwayat Imam Muslim dari 
Jabir bin Abdullah (Muslim, 1994, h. 692). Teladan dan contoh peran ayah sebagai pendidik bagi anak dari para ulama dan salafusshalih juga dapat dibaca dalam buku karya Mohammad Akram Nadwi (2007), Al-Muhaddithat; The Women Scholars in Islam.

5. Peran ayah sebagai Teman bermain (Playmates). Dalam hal ini terdapat banyak hadits yang menjelaskan sikap Nabi Muhamad SAW bermain dengan anak-anak, seperti dengan anak dan cucunya, Hasan, Husain dan Usamah bin Zaid. Juga terhadap anak-anak kecil lainnya.

6. Peran ayah sebagai Sahabat (Friend), Nabi SAW telah memberikan berkaitan dengan peran sebagai sahabat bagi anak seperti dalam hadits Shahih riwayat Imam Bukhari.

Teori peran ayah dalam perspektif Islam ini menekankan pada aspek kepemimpinan yang tidak mendapatkan penekanan khusus dan bahkan tidak pada teori-teori fathering yang sudah ada. Aspek kepemimpinan yang paling penting dari seorang ayah dalam hal ini adalah keteladanan yang lahir dari keshalihan atau sikap hidup yang baik yang dijadikan contoh oleh anak dan keluarga. Parameternya adalah ketaatan menjalankan ibadah diiringi akhlak atau perilaku yang terpuji. Adapun terhadap lima aspek lainnya maka penulis berupaya mencarikan dasar dan pijakan dari sumber-sumber ajaran Islam seperti telah disebutkan diatas.

Tujuan penelitian ini adalah untuk mengetahui sejauhmana peran ayah terhadap anak dan bagaimana implementasinya dalam perspektif ajaran Islam yang diukur dari enam indikator sebagaimana teori yang penulis kembangkan. Penelitian ini penting untuk membuktikan apakah benar anggapan dan pandangan yang menilai bahwa sosok ayah kurang berperan kecuali hanya pada aspek penanggung jawab kebutuhan ekonomi semata. Dengan dasar dan landasan teori Islamic Fathering yang bersumber pada ajaran Islam, sudah seharusnya seorang ayah muslim dapat memainkan peran lainnya selain peran sebagai pencari nafkah.

\section{Metode}

Penelitian ini menggunakan pendekatan kualitatif dengan metode analisis-deskriptif. Dengan menggunakan metode ini, peneliti mengidentifikasi, mempelajari, dan kemudian membuat sintesa data untuk memperoleh suatu pemahaman tentang konsep dan fakta. Adapun jenis penelitian yang digunakan adalah penelitian survey. Penelitian survey digunakan untuk mengumpulkan data dan informasi tentang populasi yang besar dengan menggunakan sampel yang relative kecil (Sukmadinata, 2010)

Populasi dalam penelitian ini berjumlah 2000 siswa Madrasah Aliyah (MA) kelas XI jurusan IPA, IPS dan Agama dari lima sekolah yaitu di Madrasah Aliyah Negeri (MAN) 1 Grogol, MAN 16, MAN 17, MAN 40 dan MAN. Seluruh sekolah berada di wilayah Jakarta Barat yang memang memiliki jumlah Madrasah Aliyah Negeri sebanyak enam (6) sekolah. Usia siswa adalah antara 16-18 tahun dengan domisili yang umunya berasal dari wilayah Jakarta Barat dan sebagian kecil dari Banten. Penelitian dilakukan sejak bulan September 2015 sampai dengan bulan Maret 2016.

Prosedur dan teknik pengambilan sampel dilakukan dengan teknik probability sampling atau random sampling yang diambil secara cluster random sampling dimana setiap sekolah dihitung kelasnya, kemudian kelas yang terpilih dijadikan sampel penelitian, dengan demikian mendapatkan 500 siswa.

Data dalam penelitian ini adalah; (1) angket berupa kuesioner tentang peran ayah kepada anak, (2) hasil wawancara dengan kepala sekolah, wakil kepala sekolah dan guru tentang aktifitas siswa, (3) observasi dari pengamatan terhadap siswa dan sekolah tempat penelitian, (4) dokumen tertulis maupun gambar, dan (5) literatur atau kajian pustaka terhadap teori-teori yang berkaitan dengan penelitian. Untuk mengukur peran ayah terhadap anak dari 
sudut persepsi anak penulis menggunakan instrumen penelitian berupa angket yang diberikan kepada 500 responden. Kisi-kisi pernyataan yang dijadikan indikator untuk mengukur enam peran ayah dalam perspektif Islam berjumlah 40 pernyataan.

Teknik analisis data yang dilakukan dalam penelitian ini menggunakan proses yang diajukan Lodico, Spaulding dan Voegtle (2006:311), yang menyatakan bahwa proses analisis data kualitatif merupakan suatu prosedur yang berkelanjutan dan berulang secara siklus dari mengorganisasi dan memeriksa data hingga membuat interpretasi dan kesimpulan akhir. Data yang didapatkan dari hasil observasi lapangan, hasil angket dan wawancara dikumpulkan untuk kemudian diinterpretasikan dan disimpulkan.

\section{Hasil}

Karakteristik responden yang berasal dari siswa dan siswi kelas X, XI dan XII Madrasah Aliyah Negeri (MAN), adalah pelajar di usia remaja dengan rentang usia antara 14 sampai dengan 17 tahun.

Karakteristik Sekolah adalah sekolah Negeri yang berada di bawah naungan Departemen Agama. Karena itu secara kelayakan bangunan maupun sarana dan prasarana sudah cukup baik dan memadai untuk mendukung proses belajar mengajar yang baik.
Berdasarkan hasil observasi lapangan didapatkan data bahwa karakteristik sekolah tempat penelitian adalah sekolah berbasis keagamaan yang menekankan pada aspek religuisitas dan akhlak mulia. Hal tersebut dapat dilihat dari visi, misi, program dan tata tertib serta pakain seragam yang digunakan guru dan sekolah. Keberadaan sekolah yang berada di kota Besar Jakarta sedikit banyak tentu memberikan dampak dan pengaruh kepada siswa. Secara umum tingkat ekonomi siswa berasal dari kalangan ekonomi menengah dan menengah ke bawah, dan hanya sebagian kecil saja yang berasal dari kalangan menengah atas.

\section{Dimensi peran Ayah sebagai Pemimpin} (Leader). Berdasarkan hasil angket yang terlihat pada Tabel I, secara keseluruhan, terhadap pernyataan "Apakah ayah menjadi teladan dalam ibadah, sikap dan kepemimpinan". terdapat 44,7 persen responden yang menjawab selalu, sebanyak 21,8 persen menjawab sering, 9 persen menjawab jarang sekali, 16,6 persen menjawab kadang-kadang, dan sebanyak 8,0 persen responden yang menjawab tidak pernah. Dari sembilan indikator peran pemimpin seorang ayah muslim, maka pernyataan nomor 6 yaitu, Ayah selalu mendoakan anaknya mendapatkan jawaban paling tinggi untuk jawaban selalu yaitu sebesar 81,2 persen.

Tabel. 1

Peran Ayah Sebagai Pemimpin

\begin{tabular}{|c|c|c|c|c|c|c|c|c|c|c|c|c|c|}
\hline \multirow[t]{2}{*}{ No } & \multirow{2}{*}{$\begin{array}{c}\text { Indikator } \\
\text { (Perny.) }\end{array}$} & \multicolumn{2}{|c|}{$\begin{array}{c}(1) \\
\text { Selalu } \\
\end{array}$} & \multicolumn{2}{|c|}{$\begin{array}{c}(2) \\
\text { Sering } \\
\end{array}$} & \multicolumn{2}{|c|}{$\begin{array}{c}\text { (3) } \\
\text { Jarang Sekali }\end{array}$} & \multicolumn{2}{|c|}{$\begin{array}{c}\text { (4) } \\
\text { Kadang-kadang } \\
\end{array}$} & \multicolumn{2}{|c|}{$\begin{array}{c}\text { (5) } \\
\text { Tidak Pernah } \\
\end{array}$} & \multicolumn{2}{|c|}{ JUMLAH } \\
\hline & & Mean & $(\%)$ & Mean & $(\%)$ & Mean & $(\%)$ & Mean & $(\%)$ & Mean & $(\%)$ & Sum & $(\%)$ \\
\hline 1 & 1 & 359 & $71,8 \%$ & 60 & $12 \%$ & 30 & $6 \%$ & 44 & $8,8 \%$ & 7 & $1,4 \%$ & 500 & $100 \%$ \\
\hline 2 & 2 & 130 & $26 \%$ & 140 & $28 \%$ & 68 & $13,6 \%$ & 142 & $28,4 \%$ & 20 & $4 \%$ & 500 & $100 \%$ \\
\hline 3 & 3 & 310 & $26 \%$ & 110 & $28 \%$ & 25 & $13,6 \%$ & 44 & $28,4 \%$ & 11 & $2,2 \%$ & 500 & $100 \%$ \\
\hline 4 & 4 & 151 & $30,2 \%$ & 130 & $26 \%$ & 40 & $8 \%$ & 107 & $21,4 \%$ & 72 & $14,4 \%$ & 500 & $100 \%$ \\
\hline 5 & 5 & 305 & $61 \%$ & 110 & $22 \%$ & 22 & $4,4 \%$ & 55 & $11 \%$ & 8 & $1,6 \%$ & 500 & $100 \%$ \\
\hline 6 & 6 & 406 & $81,2 \%$ & 66 & $13,2 \%$ & 10 & $2 \%$ & 11 & $2,2 \%$ & 7 & $1,4 \%$ & 500 & $100 \%$ \\
\hline 7 & 7 & 179 & $35,8 \%$ & 104 & $20,8 \%$ & 75 & $15 \%$ & 93 & $18,6 \%$ & 49 & $9,8 \%$ & 500 & $100 \%$ \\
\hline 8 & 8 & 94 & $18,8 \%$ & 78 & $15,6 \%$ & 57 & $11,4 \%$ & 114 & $22,8 \%$ & 157 & $31,4 \%$ & 500 & $100 \%$ \\
\hline 9 & 9 & 265 & $53 \%$ & 140 & $28 \%$ & 17 & $3,4 \%$ & 47 & $9,4 \%$ & 31 & $6,2 \%$ & 500 & $100 \%$ \\
\hline 10 & Jumlah & 223 & $44,7 \%$ & 109 & $21,8 \%$ & 45 & $9 \%$ & 83 & $16,6 \%$ & 40 & $\mathbf{8 , 0 \%}$ & 500 & $100 \%$ \\
\hline
\end{tabular}

Dimensi Peran Ayah Sebagai Penyedia Kebutuhan Ekonomi (Economic
Provider). Berdasarkan hasil angket yang terlihat pada Tabel II secara keseluruhan,

Tadarus Tarbawy. Vol. 1 No. 1 Jan-Jun 2019. 
terhadap pernyataan "Apakah Ayah berperan sebagai penyedia kebutuhan ekonomi, maka hasilnya adalah sebanyak 60,8 persen responden menjawab selalu, 20,6 persen responden menjawab sering, 4 persen responden menjawab jarang sekali, 11,6 persen responden menjawab kadangkadang dan 3,0 persen responden yang menjawab tidak pernah. Dari enam indikator peran ayah sebagai penyedia kebutuhan ekonomi maka jawaban terbesar untuk selalu sebesar 86,8 persen adalah pada pernyataan nomor 15, yaitu 'Ayah bekerja keras untuk mencukupi kebutuhan anak'. Sedangkan pernyataan nomor 13 yaitu ayah membayar dan melunasi biaya sekolah adalah yang relatif paling kecil yaitu

persen.

Tabel. 2

Peran Ayah Sebagai Penyedia Kebutuhan Ekonomi

\begin{tabular}{|c|c|c|c|c|c|c|c|c|c|c|c|c|c|}
\hline \multirow[t]{2}{*}{ No } & \multirow{2}{*}{$\begin{array}{l}\text { Indikator } \\
\text { (Perny.) }\end{array}$} & \multicolumn{2}{|c|}{$\begin{array}{c}(1) \\
\text { Selalu }\end{array}$} & \multicolumn{2}{|c|}{$\begin{array}{c}(2) \\
\text { Sering }\end{array}$} & \multicolumn{2}{|c|}{$\begin{array}{c}\text { (3) } \\
\text { Jarang Sekali }\end{array}$} & \multicolumn{2}{|c|}{$\begin{array}{c}(4) \\
\text { Kadang-kadang } \\
\end{array}$} & \multicolumn{2}{|c|}{$\begin{array}{c}(5) \\
\text { Tidak Pernah }\end{array}$} & \multicolumn{2}{|c|}{ JUMLAH } \\
\hline & & Mean & $(\%)$ & Mean & $(\%)$ & Mean & $(\%)$ & Mean & $(\%)$ & Mean & $(\%)$ & Mean & $(\%)$ \\
\hline 1 & 10 & 299 & $59,8 \%$ & 107 & $21,4 \%$ & 20 & $4 \%$ & 62 & $12,4 \%$ & 12 & $2,4 \%$ & 500 & $100 \%$ \\
\hline 2 & 11 & 270 & $54 \%$ & 136 & $27,2 \%$ & 21 & $4,2 \%$ & 54 & $10,8 \%$ & 19 & $3,8 \%$ & 500 & $100 \%$ \\
\hline 3 & 12 & 286 & $57,2 \%$ & 101 & $20,2 \%$ & 28 & $5,6 \%$ & 67 & $13,4 \%$ & 18 & $3,6 \%$ & 500 & $100 \%$ \\
\hline 4 & 13 & 248 & $49,6 \%$ & 119 & $23,8 \%$ & 23 & $4,6 \%$ & 88 & $17,6 \%$ & 22 & $4,4 \%$ & 500 & $100 \%$ \\
\hline 5 & 14 & 286 & $57,2 \%$ & 114 & $22,8 \%$ & 23 & $4,6 \%$ & 65 & $13 \%$ & 12 & $2,4 \%$ & 500 & $100 \%$ \\
\hline 6 & 15 & 434 & $86,8 \%$ & 42 & $8,4 \%$ & 5 & $1 \%$ & 12 & $2,4 \%$ & 7 & $1,4 \%$ & 500 & $100 \%$ \\
\hline 7 & Jumlah & 304 & $60,8 \%$ & 103 & $20,6 \%$ & 20 & $4 \%$ & 58 & $11,6 \%$ & 15 & $3,0 \%$ & 500 & $100 \%$ \\
\hline
\end{tabular}

Dimensi Peran Ayah Sebagai Pelindung (Protector). Berdasarkan hasil angket yang terlihat pada Tabel III terhadap pernyataan 'Apakah Ayah berperan sebagai Pelindung bagi anak", maka secara kesuluruhan responden yang menjawab selalu mencapai 64 persen. Kemudian sebanyak 17,8 persen menjawab sering, 4,6 persen responden menjawab jarang sekali, 9,7 persen responden menjawab kadang-kadang, dan 3,8 persen responden yang menjawab tidak pernah. Pernyataan paling tinggi nilai jawabannya ada pada nomor 21 yaitu 'Ayah mengingatkan anak untuk tidak terjerumus pada perilaku menyimpang seperti minum alkohol, narkoba dan pergaulan bebas'. Sebanyak 83,4 persen responden menjawab selalu.

Tabel. 3

Peran Ayah Sebagai Pelindung

\begin{tabular}{|c|c|c|c|c|c|c|c|c|c|c|c|c|c|}
\hline \multirow[t]{2}{*}{ No } & \multirow[t]{2}{*}{$\begin{array}{c}\text { Indikator } \\
\text { (Perny.) }\end{array}$} & \multicolumn{2}{|c|}{$\begin{array}{c}\text { (1) } \\
\text { Selalu }\end{array}$} & \multicolumn{2}{|c|}{$\begin{array}{c}(2) \\
\text { Sering }\end{array}$} & \multicolumn{2}{|c|}{$\begin{array}{c}\text { (3) } \\
\text { Jarang Sekali }\end{array}$} & \multicolumn{2}{|c|}{$\begin{array}{c}(4) \\
\text { Kadang- } \\
\text { kadang }\end{array}$} & \multicolumn{2}{|c|}{$\begin{array}{c}\text { (5) } \\
\text { Tidak Pernah }\end{array}$} & \multicolumn{2}{|c|}{ JUMLAH } \\
\hline & & Mean & $(\%)$ & Mean & $(\%)$ & Mean & $(\%)$ & Mean & $(\%)$ & Mean & $(\%)$ & Mean & $(\%)$ \\
\hline 1 & 16 & 354 & $70,8 \%$ & 77 & $15,4 \%$ & 19 & $3,8 \%$ & 42 & $8,4 \%$ & 8 & $1,6 \%$ & 500 & $100 \%$ \\
\hline 2 & 17 & 226 & $45,2 \%$ & 113 & $22,6 \%$ & 38 & $7,6 \%$ & 111 & $22,2 \%$ & 12 & $2,4 \%$ & 500 & $100 \%$ \\
\hline 3 & 18 & 364 & $72,8 \%$ & 88 & $17,6 \%$ & 18 & $3,6 \%$ & 25 & $5 \%$ & 5 & $1 \%$ & 500 & $100 \%$ \\
\hline 4 & 19 & 208 & $41,6 \%$ & 117 & $23,4 \%$ & 52 & $10,4 \%$ & 96 & $19,2 \%$ & 27 & $5,4 \%$ & 500 & $100 \%$ \\
\hline 5 & 20 & 371 & $74,2 \%$ & 63 & $12,6 \%$ & 14 & $2,8 \%$ & 11 & $2,2 \%$ & 41 & $8,2 \%$ & 500 & $100 \%$ \\
\hline 6 & 21 & 417 & $83,4 \%$ & 42 & $8,4 \%$ & 6 & $1,2 \%$ & 12 & $2,4 \%$ & 23 & $4,6 \%$ & 500 & $100 \%$ \\
\hline 7 & 22 & 301 & $60,2 \%$ & 124 & $24,8 \%$ & 15 & $3 \%$ & 42 & $8,4 \%$ & 18 & $3,6 \%$ & 500 & $100 \%$ \\
\hline 8 & Jumlah & 320 & $64 \%$ & 89 & $17,8 \%$ & 23 & $4,6 \%$ & 49 & $9,7 \%$ & 19 & $3,8 \%$ & 500 & $100 \%$ \\
\hline
\end{tabular}

Dimensi Peran Ayah Sebagai Pendidik (Educator). Berdasarkan hasil angket yang terlihat pada Tabel IV terhadap pernyataan Ayah berperan sebagai pendidik untuk

Tadarus Tarbawy. Vol. 1 No. 1 Jan-Jun 2019. 
anak, maka secara kesuluruhan responden yang menjawab selalu mencapai 40,8 persen, sebanyak 20 persen menjawab sering, 9,3 persen menjawab jarang sekali,
18 persen menjawab kadang-kadang dan 11,9 persen responden menjawab tidak pernah. Pernyataan paling tinggi nilai jawabannya ada pada nomor 21 yaitu

Tabel. 4

Peran Ayah Sebagai Pendidik

\begin{tabular}{|c|c|c|c|c|c|c|c|c|c|c|c|c|c|}
\hline \multirow[t]{2}{*}{ No } & \multirow[t]{2}{*}{$\begin{array}{l}\text { Indikator } \\
\text { (Perny.) }\end{array}$} & \multicolumn{2}{|c|}{$\begin{array}{c}(1) \\
\text { Selalu }\end{array}$} & \multicolumn{2}{|c|}{$\begin{array}{c}(2) \\
\text { Sering }\end{array}$} & \multicolumn{2}{|c|}{$\begin{array}{c}\text { (3) } \\
\text { Jarang Sekali }\end{array}$} & \multicolumn{2}{|c|}{$\begin{array}{c}\text { (4) } \\
\text { Kadang- } \\
\text { kadang }\end{array}$} & \multicolumn{2}{|c|}{$\begin{array}{c}(5) \\
\text { Tidak Pernah }\end{array}$} & \multicolumn{2}{|c|}{ JUMLAH } \\
\hline & & Mean & $(\%)$ & Mean & $(\%)$ & Mean & $(\%)$ & Mean & $(\%)$ & Mean & $(\%)$ & Mean & $(\%)$ \\
\hline 1 & 23 & 188 & $37,6 \%$ & 115 & $23 \%$ & 58 & $11,6 \%$ & 105 & $21 \%$ & 34 & $6,8 \%$ & 500 & $100 \%$ \\
\hline 2 & 24 & 396 & $79,2 \%$ & 76 & $15,2 \%$ & 9 & $1,8 \%$ & 15 & $3 \%$ & 4 & $0,8 \%$ & 500 & $100 \%$ \\
\hline 3 & 25 & 377 & $75,4 \%$ & 89 & $17,8 \%$ & 15 & $3 \%$ & 11 & $2,2 \%$ & 8 & $1,6 \%$ & 500 & $100 \%$ \\
\hline 4 & 26 & 174 & $34,8 \%$ & 143 & $28,6 \%$ & 46 & $9,2 \%$ & 113 & $22,6 \%$ & 24 & $4,8 \%$ & 500 & $100 \%$ \\
\hline 5 & 27 & 101 & $20,2 \%$ & 102 & $20,4 \%$ & 75 & $15 \%$ & 165 & $33 \%$ & 57 & $11,4 \%$ & 500 & $100 \%$ \\
\hline 6 & 28 & 115 & $23 \%$ & 101 & $20,2 \%$ & 82 & $16,4 \%$ & 139 & $27,8 \%$ & 63 & $12,6 \%$ & 500 & $100 \%$ \\
\hline 7 & 29 & 78 & $15,6 \%$ & 63 & $12,6 \%$ & 47 & $9,4 \%$ & 70 & $14 \%$ & 242 & $48,4 \%$ & 500 & $100 \%$ \\
\hline 8 & 30 & 201 & $40,2 \%$ & 121 & $24,2 \%$ & 40 & $8 \%$ & 91 & $18,2 \%$ & 47 & $9,4 \%$ & 500 & $100 \%$ \\
\hline 9 & Jumlah & 203 & $40,8 \%$ & 100 & $20 \%$ & 48 & $9,3 \%$ & 90 & $18 \%$ & 59 & $11,9 \%$ & 500 & $100 \%$ \\
\hline
\end{tabular}

Peran Ayah Sebagai Teman Bermain (Playmates). Data menunjukan bahwa terhadap pernyataan Ayah berperan sebagai teman bermain bagi anak maka sebanyak 29 persen responden menjawab selalu, kemudian 19,5 persen menjawab sering, 14,6 persen responden menjawab jarang sekali, dan 10,9 persen responden menjawab tidak pernah. Dari lima indikator peran ayah sebagai teman bermain maka jawaban paling besar yaitu 54 persen yang menjawab selalu terdapat pada pernyataan nomor 35 yaitu 'Anak memiliki banyak kenangan indah bersama ayah saat masih kecil'. Sedangkan jawaban paling rendah untuk jawaban selalu hanya 7,4 persen terdapat pada pernyataan nomor 34 yaitu 'Ayah mengajak anak berolahraga atau bersepeda'.

Tabel. 5

Peran Ayah Sebagai Teman Bermain

\begin{tabular}{|c|c|c|c|c|c|c|c|c|c|c|c|c|c|}
\hline \multirow[t]{2}{*}{ No } & \multirow{2}{*}{$\begin{array}{c}\text { Indikator } \\
\text { (Perny.) }\end{array}$} & \multicolumn{2}{|c|}{$\begin{array}{c}(1) \\
\text { Selalu }\end{array}$} & \multicolumn{2}{|c|}{$\begin{array}{c}(2) \\
\text { Sering }\end{array}$} & \multicolumn{2}{|c|}{$\begin{array}{c}\text { (3) } \\
\text { Jarang Sekali }\end{array}$} & \multicolumn{2}{|c|}{$\begin{array}{c}\text { (4) } \\
\text { Kadang-kadang }\end{array}$} & \multicolumn{2}{|c|}{$\begin{array}{c}\text { (5) } \\
\text { Tidak Pernah }\end{array}$} & \multicolumn{2}{|c|}{ JUMLAH } \\
\hline & & Mean & $(\%)$ & Mean & $(\%)$ & Mean & $(\%)$ & Mean & $(\%)$ & Mean & $(\%)$ & Mean & $(\%)$ \\
\hline 1 & 31 & 175 & $35 \%$ & 112 & $22,4 \%$ & 67 & $13,4 \%$ & 119 & $23,8 \%$ & 27 & $5,4 \%$ & 500 & $100 \%$ \\
\hline 2 & 32 & 197 & $39,4 \%$ & 135 & $27 \%$ & 42 & $8,4 \%$ & 105 & $21 \%$ & 21 & $4,2 \%$ & 500 & $100 \%$ \\
\hline 3 & 33 & 53 & $10,6 \%$ & 73 & $14,6 \%$ & 102 & $20,4 \%$ & 207 & $41,4 \%$ & 65 & $13 \%$ & 500 & $100 \%$ \\
\hline 4 & 34 & 37 & $7,4 \%$ & 56 & $11,2 \%$ & 107 & $21,4 \%$ & 163 & $32,6 \%$ & 137 & $27,4 \%$ & 500 & $100 \%$ \\
\hline 5 & 35 & 274 & $54,8 \%$ & 111 & $22,2 \%$ & 47 & $9,4 \%$ & 44 & $8,8 \%$ & 24 & $4,8 \%$ & 500 & $100 \%$ \\
\hline 6 & Jumlah & 145 & $29 \%$ & 98 & $19,5 \%$ & 74 & $14,6 \%$ & 128 & $25,5 \%$ & 55 & $10,9 \%$ & 500 & $100 \%$ \\
\hline
\end{tabular}

Peran Ayah Sebagai Sahabat (Friend). Data menunjukan dari pernyataan 'Ayah berperan sebagai sahabat bagi anak' sebanyak 25,3 persen responden menjawab selalu, 19,5 persen responden menjawab sering, 14 persen responden menjawab jarang sekali, 26 persen responden menjawab kadang-kadang, dan 15 persen responden menjawab tidak pernah. Dari lima indikator peran ayah sebagai sahabat maka jawaban selalu yang paling besar yaitu 36 persen terdapat pada pernyataan nomor 38 yaitu 'ayah membuat anak merasa nyaman untuk berbicara'. Sedangkan pernyataan nomor 39 yaitu 'Ayah mendengarkan dan merespon cuhat anak' adalah paling kecil dengan jawaban $\begin{array}{llll}\text { selalu sebesar } & 10.2 & \text { persen. }\end{array}$ 
Tabel. 6

Peran Ayah Sebagai Sahabat

\begin{tabular}{|c|c|c|c|c|c|c|c|c|c|c|c|c|c|}
\hline \multirow[t]{2}{*}{ No } & \multirow[t]{2}{*}{$\begin{array}{l}\text { Indikator } \\
\text { (Perny.) }\end{array}$} & \multicolumn{2}{|c|}{$\begin{array}{c}(1) \\
\text { Selalu }\end{array}$} & \multicolumn{2}{|c|}{$\begin{array}{c}(2) \\
\text { Sering }\end{array}$} & \multicolumn{2}{|c|}{$\begin{array}{c}\text { (3) } \\
\text { Jarang Sekali }\end{array}$} & \multicolumn{2}{|c|}{$\begin{array}{c}\text { (4) } \\
\text { Kadang- } \\
\text { kadang }\end{array}$} & \multicolumn{2}{|c|}{$\begin{array}{c}\text { (5) } \\
\text { Tidak Pernah }\end{array}$} & \multicolumn{2}{|c|}{ JUMLAH } \\
\hline & & Mean & $(\%)$ & Mean & $(\%)$ & Mean & $(\%)$ & Mean & $(\%)$ & Mean & $(\%)$ & Mean & $(\%)$ \\
\hline 1 & 36 & 183 & $36,6 \%$ & 117 & $23,4 \%$ & 65 & $13 \%$ & 105 & $21 \%$ & 30 & $6 \%$ & 500 & $100 \%$ \\
\hline 2 & 37 & 129 & $25,8 \%$ & 130 & $26 \%$ & 75 & $15 \%$ & 131 & $26,2 \%$ & 35 & $7 \%$ & 500 & $100 \%$ \\
\hline 3 & 38 & 190 & $38 \%$ & 119 & $23,8 \%$ & 53 & $10,6 \%$ & 118 & $23,6 \%$ & 20 & $4 \%$ & 500 & $100 \%$ \\
\hline 4 & 39 & 51 & $10,2 \%$ & 38 & $7,6 \%$ & 85 & $17 \%$ & 163 & $32,6 \%$ & 163 & $32,6 \%$ & 500 & $100 \%$ \\
\hline 5 & 40 & 79 & $15,8 \%$ & 82 & $16,4 \%$ & 75 & $15 \%$ & 134 & $26,8 \%$ & 130 & $26 \%$ & 500 & $100 \%$ \\
\hline 6 & Jumlah & 127 & $25,3 \%$ & 98 & $19,5 \%$ & 70 & $14 \%$ & 130 & $26 \%$ & 75 & $15 \%$ & 500 & $100 \%$ \\
\hline
\end{tabular}

Perbandingan Hasil Angket Enam Dimensi Peran Ayah. Dari enam dimensi peran ayah terhadap anak dalam perspektif Islam didapatkan hasil bahwa peran ayah sebagai pemimpin sebesar 44,9 persen, peran ayah sebagai penyedia kebutuhan ekonomi sebesar 60,8 persen, peran ayah sebagai pelindung sebesar 64 persen, peran ayah sebagai pendidik sebesar 40,8 persen, peran ayah sebagai teman bermain sebesar 29 persen, dan peran ayah sebagai sahabat sebesar 25.3 persen. Data pada tabel VII berikut menunjukan bahwa peran ayah yang paling tinggi terdapat pada peran sebagai pelindung dan peran paling rendah terdapat pada peran sebagai sahabat bagi anak.

Tabel. 7

Perbandingan Enam Dimensi Peran Ayah Terhadap Anak Dalam Perspektif Islam

\begin{tabular}{|c|c|c|c|c|c|c|c|c|c|c|c|c|c|}
\hline \multirow[t]{2}{*}{ No } & \multirow[t]{2}{*}{$\begin{array}{l}\text { Dimensi } \\
\text { Peran }\end{array}$} & \multicolumn{2}{|c|}{$\begin{array}{c}(1) \\
\text { Selalu } \\
\end{array}$} & \multicolumn{2}{|c|}{$\begin{array}{c}(2) \\
\text { Sering }\end{array}$} & \multicolumn{2}{|c|}{$\begin{array}{c}\text { (3) } \\
\text { Jarang Sekali }\end{array}$} & \multicolumn{2}{|c|}{$\begin{array}{c}\text { (4) } \\
\text { Kadang-kadang }\end{array}$} & \multicolumn{2}{|c|}{$\begin{array}{c}(5) \\
\text { Tidak Pernah }\end{array}$} & \multicolumn{2}{|c|}{ Jumlah } \\
\hline & & Mean & $(\%)$ & Mean & $(\%)$ & Mean & $(\%)$ & Mean & $(\%)$ & Mean & $(\%)$ & Mean & $(\%)$ \\
\hline 1 & Pemimpin & 223 & $44,7 \%$ & 109 & $21,8 \%$ & 45 & $9 \%$ & 83 & $16,6 \%$ & 40 & $8,0 \%$ & 500 & $100 \%$ \\
\hline 2 & $\begin{array}{l}\text { Pen. Keb. } \\
\text { Ekonomi }\end{array}$ & 304 & $60,8 \%$ & 103 & $20,6 \%$ & 20 & $4 \%$ & 58 & $11,6 \%$ & 15 & $3,0 \%$ & 500 & $100 \%$ \\
\hline 3 & Pelindung & 320 & $64 \%$ & 89 & $17,8 \%$ & 23 & $4,6 \%$ & 49 & $9,7 \%$ & 19 & $3,8 \%$ & 500 & $100 \%$ \\
\hline 4 & Pendidik & 203 & $40,8 \%$ & 100 & $20 \%$ & 48 & $9,3 \%$ & 90 & $18 \%$ & 59 & $11,9 \%$ & 500 & $100 \%$ \\
\hline 5 & $\begin{array}{c}\text { Teman } \\
\text { Bermain }\end{array}$ & 145 & $29 \%$ & 98 & $19,5 \%$ & 74 & $14,6 \%$ & 128 & $25,5 \%$ & 55 & $10,9 \%$ & 500 & $100 \%$ \\
\hline \multirow[t]{2}{*}{6} & Sahabat & 127 & $25,3 \%$ & 98 & $19,5 \%$ & 70 & $14 \%$ & 130 & $26 \%$ & 75 & $15 \%$ & 500 & $100 \%$ \\
\hline & $(\%)$ & \multicolumn{2}{|c|}{$44 \%$} & \multicolumn{2}{|c|}{$20 \%$} & \multicolumn{2}{|c|}{$9 \%$} & \multicolumn{2}{|c|}{$18 \%$} & \multicolumn{2}{|c|}{$9 \%$} & 500 & $100 \%$ \\
\hline
\end{tabular}

\section{B. PEMBAHASAN}

Pandangan dan sikap yang lebih menitikberatkan peran ayah sebagai pencari nafkah atau pada aspek pemenuhan kebutuhan ekonomi semata sebagaimana dipaparkan pada bagian pendahuluan tulisan ini nampaknya belum banyak berubah sampai saat ini. Hal ini dapat dilihat dari hasil penelitian seperti dapat dilihat pada grafik VII. Dari grafik perbandingan enam dimensi peran ayah didapatkan data bahwa peran ayah yang paling tinggi yang dirasakan oleh anak adalah peran sebagai pelindung atau protector yang mencapai angka 64 persen. Berikutnya adalah peran ayah sebagai penyedia kebutuhan ekonomi atau pencari nafkah sebesar 60,8 persen. Sedangkan peran terendah ayah yang dirasakan anak adalah peran sebagai sahabat anak yang hanya 25,3 persen kemudian peran sebagai teman bermain anak sebesar 29 persen. Adapun peran ayah sebagai pemimpin juga tidak terlalu tinggi yaitu sebesar 44,9 persen dan peran sebagai pendidik atau guru bagi anaknya juga sama hanya 40,8 persen.

Dengan kata lain, penelitian ini membuktikan bahwa peran ayah masih belum beranjak dari peran tradisionalnya sebagai pelindung dan pencari nafkah bagi anak seperti pernah dikatakan Margaret Mead, seorang ahli antropologi Amerika terkenal yang menyampaikan bahwa model hubungan ibu-anak dalam masyarakat saat 
ini hanya cocok untuk setengah juta tahun yang lalu, yaitu seorang laki-laki yang pulang ke rumahnya yang ada di gua-gua untuk makan dan berhubungan intim dengan pasangannya, dan terkadang mencari keberadaan anaknya.

Hasil penelitian ini menjelaskan bahwa peran ayah dalam perspektif Islam ini masih kecil dan jauh dari harapan. Aspek kepemimpinan dan keteladanan yang menjadi aspek paling penting dari teori dalam penelitian ini hanya mencapai angka 44,9 persen. Demikian pula halnya dimensi peran ayah sebagai pendidik yang memiliki peran amat signifikan dan menentukan bagi masa depan anak hanya mencapai angka 40,8 persen. Kelemahan pada aspek kepemimpinan inilah yang menjadi sumber mengapa peran-peran ayah lainnya menjadi tidak maksimal seperti peran sebagai pendidik yang hanya berkisar 40,8 persen. Lemahnya pemahaman ayah sebagai pemimpin menyebabkan munculnya anggapan bahwa peran pendidik bagi anak diserahkan kepada ibu atau lembaga pendidikan, sedangkan tugas ayah adalah menyediakan kebutuhan atau keperluan belajarnya saja.

Secara keseluruhan peran ayah terhadap anak dalam perspektif Islam terhitung belum siginifikan. Karena dari data tersebut didapatkan hasil hanya 44 persen responden yang menjawab selalu, 20 persen menjawab sering, 9 persen menjawab jarang sekali, 18 persen menjawab kadang-kadang, dan 9 persen menjawab tidak pernah. Angka 44 persen tentulah sangat kecil, bahkan jika ditambahkan dengan jawaban sering sebesar 20 persen maka hasilnya hanyalah 64 persen atau belum menyentuh angka 75 persen yang menjadi standar signifikansi sesuatu.

Hasil penelitian ini tentu menambah kekhawatiran kita di tengah kondisi maraknya kejahatan yang terjadi di kalangan anak-anak dan remaja terutama sepanjang tahun 2016 ini. Dalam kondisi masyarakat yang semakin majemuk dan terbuka seperti saat ini, anak perlu mendapatkan pendidikan sosial yang memadai dari orang tua terutama ayah. Amato (1994) dalam penelitiannya membuktikan bahwa kualitas hubungan ayah yang baik terhadap anaknya berpengaruh besar terhadap kecerdasan sosial anak.

Dari penelitian ini juga ditemukan bahwa peran ayah sebagai teman dan teman bermain sangatlah kecil, yaitu sebesar 29 persen dan 25,3 persen saja. Padahal salah satu faktor kejahatan yang terjadi di kalangan anak-anak dan remaja selain mereka kehilangan sosok teladan, juga karena rumah tidak menjadi teman yang nyaman bagi mereka. Sosok ayah yang tidak mampu menjadi teman bermain yang menyenangkan atau sahabat untuk curhat bagi anak menyebabkan mereka mencari di luara rumah, kepada teman dan dunia maya. Beberapa kasus yang muncul ke permukaan seperti tragedi Yuyun di Lampung dan lainlain membuktikan hal tersebut.

\section{KESIMPULAN DAN SARAN}

Kesimpulan. Penelitian ini berkesimpulan bahwa peran ayah terhadap anak dalam perspektif Islam masih kecil dan tidak signifikan. Ayah muslim belum mampu menginplementasikan perannya sebagaimana seharusnya. Dari enam dimensi peran yang seharusnya dilakukan seorang ayah maka aspek paling tinggi ada pada peran sebagai pelindung dan pencari nafkah. Dua peran yang sesungguhnya betapapun pentingnya- adalah hal yang lumrah dan naluriah semata, karena bahkan hewan juga melakukan dua peran hal tersebut. Adapun peran-peran lainnya belum mampu dilaksanakan dengan baik. Aspek kepemimpinan dan peran sebagai pendidik yang memiliki landasan yang sangat kuat dalam ajaran Islam belum mampu menyentuh angka 50 persen. Dan yang mengkhawatirkan adalah dimensi peran ayah sebagai sahabat dan teman bermain bagi anak yang bahkan dibawah 
angka 30 persen. Padahal dua peran ini sangat penting untuk menjaga anak dari perilaku menyimpang dan kriminalitas yang kini semakin meningkat di kalangan anakanak dan remaja.

Saran. Atas hasil penelitian ini penulis mengharapkan; Pertama, penting bagi setiap orang tua khusunya ayah untuk memahami urgensi peran ayah dan segala implikasinya. Kedua, bagi para ulama, tokoh dan kalangan muslim terpelajar harus memberikan pemahaman yang jelas dan komprehensif akan pentingnya peran ayah dari sudut pandang agama Islam. Ketiga bagi kalangan akdemisi dan peneliti perlu dilakukan penelitian lebih lanjut sejauhmana pengaruh peran ayah terhadap aspek yang terdapat pada diri anak baik aspek sikap dan moralitas, prestasi, kecerdasan intelektual, kecerdsan emosi dan sosial anak dan aspek-aspek lainnya. Dan keempat, untuk para pengambil kebijakan untuk melakukan upaya membuat regulasi yang memungkinkan seorang ayah bisa memerankan perannya secara maksimal.

\section{DAFTAR PUSTAKA}

Al-Bukhari, Abu Abdillah Muhamad bin Ismail. (2014). Shahih Bukhari, Kairo: Syirkah al-Quds

Al-Ghamidi, Abdurrahman bin Abdul Khaliq. (1418). Madkhal ila alTarbiyah al-Islamiyah, Riyadh, Dar al-Khiriji

Al-Jauziyah, Ibnu Qayyim. (2005).Tuhfat al-Maudud Bi Ahkam al-Maulud, Takhrij Muhammad Nashiruddin AlAlbani, Kairo: Dar al-Atsar

Amato. P.R, (1994). Father-Child Relations, mother-child relations, and offspring psychologica well being in early adulthood, . Journal of marriage and Family

Azra, Azyumardi. (2000). Pendidikan Islam; Tradisi dan Modernisasi Menuju Milenium Baru, Jakarta, Logos
Baharits, Adnan Hasan Shalih. (1991). Mas'uliyat Al-Ab al-Muslim Fi Tarbiyat al-Walad Fi Marhalat AlTufulah, Jeddah: Darul Mujtama

Belsky, A. Jaim, J. \& K. Crcnic. (2015). Beyond Fathering Behaviors: Types of Dads, Journal Family Pshchology, V. 10/4, http://www.questio.com/ diakses pada 10/12/2015

Brown, T. (2000). What Special about Father's, Involvement? dikutip dari http://www.balconesbank.community. com/voices/father.asp, $\quad$ pada $10 / 12 / 2015$

Cabrera, Natasha J. (2002). "Fathers" Child Development, Ed. Neil J. Sallkind, New York: Macmillan Reference USA

Darity, William A., Jr, (Ed.). (2008). International Encyclopedia of Sicial Sciences, Vol. 3.2. Detroit: Macmillan References USA

Erawati, Muna. (2012). Model Keterlibatan Ayah Dalam Pengasuhan, Artikel pada Jurnal STAIN SALATIGA

Evans, G.D., The Common Roles of Fahers: The Five Ps. (1999). dikutip dari http://edis.ifas..ufl..edu/Body HE137, pada 10/12/2015

Hilliard, D.R., Qualities of Succesfull Father-Child Relationship. (1996). dikutip dari http://www.YouthandReligion.org/Re sources/ref_age.htm/, 10/112/2015

Ibnu Bukhari, Ihsan Baihaqi. (2013). Yuk Jadi Orang Tua Shalih Sebelum Meminta Anak Shalih, Bandung: Mizania

Istadi, Irawati. (2014). Mendidik Dengan Cinta; Bangun Karakter Remaja, Cakrawala Publishing

Kurk, Edwark. (2015). Father Absence, Father Deficit, Father Hunger The Vital Importance of Paternal Presence in Children's Lives, Phschology Today

Lamb, Michael E, \& Lewis, Charlie. (2003). European Journal of Phschology of Education, Vol . XVIII, I.S.P.A 
McAdoo, J.L. (1993). Understanding Fathers: Human Services Perspectives in Theory and Practice

Muslim, Abu Al-Husain Muslim bin AlHajjaj Al-Qusyairi An-Naisaburi. (1994). Shahih Muslim, Beirut, Dar al-Fikr

National Center For Education Statistic (NCES). (2001). Measuring Father Involvement in Young's Nadwi, Muhammad Akram. (2007). AlMuhaddithat; The Womens Scholar In Islam, Interface

Publications, Oxford, London

Children Lives; Recommendations for Fatherhood Module For ECLS-B, Working Paper No. 2001-02

National Center on Father and Families (NCOF). (2015). Fathering Indicator Frame Wrk: A Tool For Quantative and Qulitative Analysis. http://www.ncoff.qse.upenn.edu/fif/F of_report.pdf. Diakses pad $10 / 12 / 2015$

National Household Education Survey (NHES). (1997). Father's Involvement in Their's Children School, Statistical Analysis Report, U.S Department of Education, NCES

National Center on Father and Families, Fathering Indicator Frame Wrk: A Tool For Quantative and Qulitative
Analysis.

http://www.ncoff.qse.upenn.edu/fif/F of_report.pdf. Diakses pada $10 / 12 / 2015$

Parke, Ross D. dan David J. Mcdowell. (2003). "Fatherhood." International Encylopedia of Marriage and Family; Ed. James J. Ponzetti, $2^{\text {nd }}$ ed, Vol 2, New York Macmillan Reference USA Parenting Pathaways. (1998). Father Role. http://fairfield.osn.edu/parent/parent diakses pada

15 Januari 2016

Ryan, Joan Aho. (1997). Lessons from Dad; a Tribute To Fatherhood, Florida, Health Communication Slameto, 2002, Peranan Ayah Dalam Pendidikan Anak dan Hubungannya Dengan Prestasi Belajarnya, Jurnal Satya Eydaya, Vol. 15 no. 1

Sofar, Charlety Chosyam. (2008). Pengembangan Karakter Melalui Pendidikan Keluarga; Studi Komparatif Teori Al-Ghazali dan Teori Kornadt, Disertasi di UIN Jakarta, PPS UIN Jakarta

Sukmadinata, Nana Syaodih. (2010). Metode Penelitian Pendidikan, Bandung, Rosda Karya

Ulwan, Abdullah Nasih. (2013). Tarbiyat al-Aulad fi al-Islam, Kairo: Dar alSalam, Cet ke-14. 